\title{
Manajemen : Sejarah Dan Penerapannya Dalam Dakwah
}

\author{
${ }^{1}$ Hasan Basri, ${ }^{2}$ Mansur \\ ${ }^{1}$ Fakultas Tarbiyah dan Ilmu Keguruan IAIN Kendari \\ ${ }^{2}$ Fakultas Ushuluddin, Adab dan Dakwah IAIN Kendari \\ email: ${ }^{1}$ hasanbasri.iainkendari@gmail.com, ${ }^{2}$ mansurrahman@yahoo.com
}

\begin{abstract}
The focus of the discussion in this paper is the position of management in the Islamic view, both in the historical and practical aspects. The core of management activity really lies in the effort to manage the cooperation of several people to achieve certain goals. Management is more the art of managing than science. In much literature, management in Islam is sometimes called al-idārah, al-tadbīr, al-nizām, and al-imārah. In this sense, management is more practical than theoretical. Practically, management has been practiced since the Prophet Adam. together with his family, continued by the Prophets thereafter until the arrival of the Prophet Muhammad., as a consummate of Islam. In the Islamic era, management was practiced within the framework of the implementation of Islam in general as a system of life, government and the development of civilization. This paper is a mixture of various literatures. This study presents the historical facts of the glory of Islam in the collective management of the lives of Muslims. The long span of the golden history of Islam proves that the management of the lives of Muslims is perfectly arranged, including in the field of management and management of da'wah. In Islamic perspective, to manage of any cooperation as a management activity. It is positioning as the regulation of activities and interactions that must be bound by the provisions of Islamic teachings. Provisions imposed by the Qur'an related to management are based on Islamic faith which teaches human connectedness with The Creator when carrying out any activity. Relationship with God will absolutely produce a person who has a moral attitude and personal integrity of the executors of management, prioritizing sincerity, honesty, trustworthiness, and fast and communicative service. Emphasis on personal existence that makes Islam the basis of its activities will make any
\end{abstract}


institutional management run well in accordance with the objectives to be achieved.

Keyword: management, management position in Islam.

\begin{abstract}
Abstrak
Fokus pembicaraan dalam tulisan ini adalah posisi manajemen dalam pandangan Islam, baik pada aspek sejarah maupun prakteknya. Inti aktivitas manajemen sesungguhnya terletak pada upaya pengelolaan kerja sama beberapa orang untuk mencapai tujuan tertentu. Manajemen lebih bersifat seni mengelola dari pada ilmu. Dalam banyak literatur, manajemen dalam Islam kadang disebut al-idārah, al-tadbīr, al-nizāam, dan al-imārah. Dalam pengertian ini, manajemen lebih bersifat praktis dari pada teoretis. Secara praktis, manajemen telah dipraktekkan sejak Nabi Adam as. bersama keluarganya, dilanjutkan oleh para Nabi sesudahnya sampai datangnya Nabi Muhammad Saw., sebagai penyempurna Islam. Di zaman Islam, manajemen dipraktekkan dalam kerangka pelaksanaan Islam secara umum sebagai sistem kehidupan, pemerintahan dan pengembangan peradaban. Tulisan ini merupakan ramuan dari berbagai literatur. Kajian ini menyajikan fakta historis kegemilangan Islam dalam sisi pengelolaan kehidupan kaum muslimin secara kolektif. Bentang panjang sejarah keemasan Islam membuktikan bahwa pengelolaan kehidupan kaum muslimin tertata sempurna termasuk dalam bidang pengelolaan dan manajemen dakwah.Dalam perspektif Islam, pengelolaan kerja sama apapun sebagai suatu kegiatan manajemen menempati posisi sebagai pengaturan aktivitas dan interaksi yang mesti terikat dengan ketentuan ajaran Islam. Ketentuan-ketentuan yang diisyaratkan oleh al-Qur'an terkait manajemen adalah berbasis pada aqidah Islam yang mengajarkan keterhubungan manusia dengan penciptanya ketika melakukan aktivitas apapun. Keterhubungan dengan Allah secara mutlak akan menghasilkan pribadi yang memiliki sikap moral dan integritas pribadi para pelaksana manajemen, mengutamakan ketulusan, keikhlasan, kejujuran, amanah, serta pelayanan yang cepat dan komunikatif. Penekanan pada adanya pribadi yang menjadikan Islam sebagai dasar
\end{abstract}


aktivitasnya akan menjadikan manajemen kelembagaan apapun berjalan baik sesuai dengan tujuan yang ingin dicapai.

Kata kunci: Manajemen, Manajemen dalam Islam.

\section{A. Pendahuluan}

Manajemen merupakan istilah yang cukup banyak digunakan dalam setiap kerja sama pada lembaga atau kelompok yang melibatkan banyak orang. Manajemen sendiri dimaknai, baik dalam pengertian sebagai seni mengelola kerja sama, ilmu tentang manajemen maupun jabatan-jabatan pimpinan di sebuah unit atau lembaga.

Istilah manajemen yang selama ini digunakan dalam hampir semua lapangan kehidupan dikenal berasal dari Barat. Begitu juga sejarah-sejarah yang diungkap untuk menelusuri jejak manajemen di dunia diambil dari sejarah bangsa-bangsa Barat dan Eropah. Jika ditelusuri lebih awal, manajemen dinisbatkan dari sejarah Yunani Kuno dan Romawi Kuno. Selanjutnya sejarahnya langsung lompat sampai pada zaman manajemen modern. Zaman Islam yang terletak antara Yunani Kuno atau Romawi Kuno dengan zaman modern, tidak dibahas secara signifikan. Hal ini menjadikan orang beranggapan bahwa manajemen memang berasal dari Barat, tidak ada kaitannya dengan Islam.

Padahal, terdapat zaman yang begitu panjang mengantarai zaman kuno dengan zaman modern. Zaman itu adalah zaman Islam yang menurut sebagian ahli dari Barat sedniri merupakan jembatan antara peradaban Yunani Kuno dengan peradaban modern. Lamanya lebih dari 10 abad sampai datangnya zaman kebangkitan di Eropah pada abad $16 \mathrm{M}$.

Hingga kini, masih sulit menemukan kajian manajemen yang genuine disandarkan pada Islam. Jika pun terdapat kajian yang mengatasnamakan Islam umumnya hanya menyajikan kajian manajemen yang dikaitkan dengan prinsip-prinsip yang ada dalam Islam. Buku-buku manajemen yang berkaitan dengan Islam pun biasanya diisi dengan kajian spesifik tentang salah satu aspek ekonomi yang dikaitkan dengan Islam, 
seperti manajemen perbankan syariah.

Meskipun demikian, telah ada upaya ilmuan muslim untuk menggali kembali sejarah yang dilupakan oleh peradaban modern itu dengan menelusuri era kemajuan Islam yang pernah menerangi dunia dengan peraban Ilahi yang melahirkan kemajuan sains dan teknologi. Kemajuan peradaban itu tidak mungkin bisa terwujud tanpa adanya perencanaan yang matang, pengaturan, pengelolaan berbagai aspek kehidupan dengan rapi, yang kini dinamakan manajemen.

Salah satu karya berbahasa Indonesia yang menjadi rujukan utama dalam kajian ini, ditulis oleh Ma'ruf Abdullah yang berjudul Manajemen Berbasis Syariah. Tulisan ini menjadi pengisi kekurangan dalam literatur manajemen dalam perspektif Islam. Kajian ini mengetengahkan sajian ilmiah mengenai manajemen dengan merujuk pada dalil-dalil syariah, disertai gambaran pelaksanaan manajemen pada masa Islam di zaman Rasulullah Saw, Khulafaurrasyidin sampai zaman Abbasiyah.

Dalam bentuk artikel, Abdul Goffar menulis Manajemen dalam Islam (Perspektif al-Qur'an dan Hadis). Dalam kajiannya, beliau menyimpulkan bahwa manajemen sebenarnya ada dalam al-Qur'an dan dipraktikkan oleh Rasulullah Saw. Namun, kajian secara rinci umat Islam dipersilahkan menafsirkan ayat-ayat dan hadis yang terkait dengan rincian praktik manajemen (Abdul Goffar 2016: 56). Hal yang sama seperti ditulis oleh M. Yacoeb dalam bidang manajemen pendidikan dengan judul Konsep Manajemen dalam Perspektif al-Qur'an: Suatu Analisis dalam bidang Administrasi Pendidikan. Semua kajian manajemen dalam perspektif Islam tersebut telah banyak membahas mengenai praktek manajemen dalam Islam. Namun, artikel ini secara spesifik membahas posisi atau kedudukan manajemen dalam Islam dari aspek sejarah perkembangan dan prakteknya dalam Islam.

Manajemen dalam pengertian umum sebagai pengelolaan kerja sama secara rapi, dalam perspektif Islam telah diletakkan pondasinya dalam al-Qur'an. Ayat berikut merupakan dalil yang sangat jelas tentang perintah 
untuk melakukan pekerjaan secara rapi dan teratur. Allah berfirman:

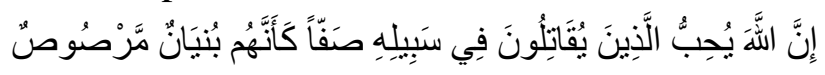

Sesungguhnya Allah menyukai orang yang berperang dijalan-Nya dalam barisan yang teratur seakan-akan mereka seperti suatu bangunan yang tersusun kokoh (TQS. al-Shaf/61: 4).

Dalam Tafsirnya, al-Sa'diy menjelaskan bahwa ayat tersebut di atas menjelaskan bahwa șaf yang dimaksud adalah barisan yang rapi dan teratur dimana antara satu dengan yang lainnya saling menguatkan untuk memerangi musuh sehingga kemenangan dapat dicapai. Karena itu, ketika Nabi Saw hadir dalam peperangan mengatur barisan dengan menempatkan para shahabat dalam posisi yang tepat tidak saling menghalangi, tetapi saling memperkuat satu sama lainnya sehingga masing-masing fokus melaksanakan tugasnya (Abd al-Rahmān bin Nāșir bin al-Sa'diy, 1420 H/2000 M: 858).

Dalam Islam, jihad adalah amalan yang paling tinggi nilainya karena melibatkan bahkan bisa mengorbankan semua sumber daya yang ada untuk berhadapan dengan kekuatan pihak lain yang secara langsung ingin menghancurkan. Karena itu manajemen tertinggi dalam amal terdapat pada jihad. Dalam sejarah tercatat bahwa sepanjang Nabi Saw., memimpin umat Islam selama 10 tahun pasca hijrah, secara umum selalu memenangi setiap peperangan. Padahal, hampir setiap peperangan yang dilakukan umat Islam selalu minimal dari segi jumlah personil. Lebih dari itu, semua sejarawan yang jujur mengakui bahwa belum pernah ada sosok yang begitu gemilang membangun sebuah peradaban yang sama sekali baru dan tangguh dalam waktu yang sangat singkat selain Nabi saw. Bahkan peradaban itu mampu bertahan sampai belasan abad setelah Nabi Saw. tiada. Hal ini menunjukkan betapa tingginya manajemen yang diterapkan oleh Nabi Saw. Permbicaraan dalam tulisan ini difokuskan pada bagaimana manajemen dan pengelolaan kaum muslimin yang dilakukan oleh para leader/manajer dalam menata seluruh aspek kehidupan mereka, termasuk pelaksanaan dakwah di dalamnya. 


\section{B. Pengertian Manajemen}

Kata manajemen terambil dari bahasa Inggris, yakni manajement (dari kata kerja manage) yang dalam kamus diartikan sebagai mengatur, mengurus, melaksanakan, atau mengelola. Sehingga secara bahasa managemen berarti ketatalaksanaan, tata pimpinan atau pengelolaan (John M. Echols dan Hassan Shadily, 2007: 372). Sebelumnya, istilah manajemen terambil dari bahasa Latin yakni manus yang artinya tangan dan agere yang berarti melakukan. Ada lagi kata dalam bahasa Italia yang dianggap sebagai asal kata manajemen, yakni managiare yang berarti melatih kuda menindakkan langkah atau kakinya.

Dalam bahasa Indonesia sendiri, pengelolaan berarti: 1) proses, cara, perbuatan mengelola, 2) proses melakukan kegiatan tertentu dengan menggerakkan tenaga orang lain, 3) proses yang membantu merumuskan kebijaksanaan dan tujuan organisasi, 4) proses yang memberikan pengawasan pada semua hal yang terlibat dalam pelaksanaan kebijaksanaan dan pencapaian tujuan (KBBI, 2002: 534).

Para ahli seperti Frederick Winslow Taylor (1856-1915 M) mengemukakan bahwa manajemen itu pada dasarnya merupakan pengelolaan kerja sama yang memberikan perhatian terhadap pengembangan organisasi dengan pertimbangan-pertimbangan ilmiah terhadap pengaturan berbagai tugas-tugas personalia (Eugene J. Benge, 1994: 6).

Dalam bahasa Arab, sulit untuk menyebutkan satu kata yang persis sama maknanya dengan kata manajemen dalam bahasa Inggris. Hal ini salah satunya disebabakan karena kekayaan kata dalam bahasa Arab dimana setiap sesuatu dapat memiliki ungkapan kata yang spesifik. Karena itu, kata manajemen dapat disebut dengan beberapa kata, seperti: idārah, tadbir, imārah, nizām. Keempat kata ini dapat digunakan secara bergantian untuk menyebut kata manajemen. Penjelasan istilah-istilah tersebut adalah sebagai berikut: 


\section{Idārah}

Dalam bahasa Arab, kata manajemen dapat diambil padanannya dengan kata al-idārah ( الادارة jamaknya ادارات ). Kata ini berasal dari akar kata (mādi), yakni adāra ( ادار ) yang artinya mengatur atau mengurus (Ahmad Warson Munawwar, 1997: 432). Dari kata ini kemudian muncul istilah idāriy yang artinya aturan administratif. Karena itu, kata al-idārah biasa diartikan administrasi.

Mungkin kata inilah yang paling populer digunakan orang dewasa ini untuk menyebut manajemen atau administrasi. Namun, kata ini tidak ditemukan dalam nash, baik al-Qur'an maupun Hadis, sehingga dipastikan bahwa kata الادارة muncul belakangan sebagai kata kontemporer.

\section{Tadbìr}

Kata tadbīr berasal dari kata dabbara ( دبَّر ) yang berarti mengatur atau mengurus. Kata ini juga bisa memiliki kemiripan makna dengan kata

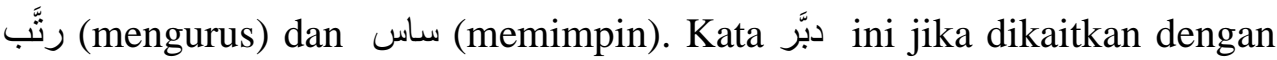
kata الامر (urusan): دبّر الامر artinya memikirkan, mempertimbangkan akibatnya baik dan buruknya (Ahmad Warson Munawwar, 1997: 384).

Berbeda dengan kata idārah, kata tadbīr dapat ditemukan dalam nash al-Qur'an seagai berikut:

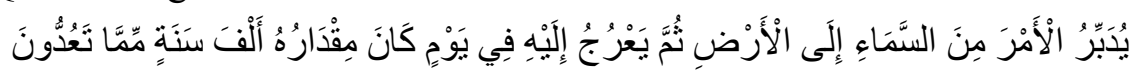

Dia mengatur urusan dari langit ke bumi, kemudian (urusan) itu naik kepadaNya dalam satu hari yang kadarnya adalah seribu tahun menurut perhitunganmu (QS. al-Sajadah/32: 5).

Kata yudabbiru dalam ayat di atas menurut Imam Ibnu Katsir dalam Tafsir Ibnu Katsir ketika membahas ayat 5 surah al-Sajdah di atas, artinya adalah bahwa Allah menurunkan perintah-Nya dari langit yang tinggi ke tempat yang jauh di bumi melalui tujuh lapis langit. Dalam perspektif manajemen, dimaknai sebagai pengambilan keputusan manajemen puncak untuk didstribusikan dan dikerjakan oleh yang diamanahi. 


\section{Nizām}

Kata niẓām (نظام berasal dari akar kata nazama (نطم) yang berarti menyusun, mengatur atau merangkai. Niz̄ām artinya susunan, tatanan, aturan atau sistem. Jika digabungkan dengan kata الحياة (hidup): نظام الحياة atau نظام الحكومة : الحكومة maka bemerintahan): نطامة aturan hidup atau sistem pemerintahan (Ahmad Warson Munawwar, 1997: 1435).

Kata nizām ini juga tidak terdapat dalam nash al-Qur'an juga dalam hadis. Hanya terdapat dalam sebuah ungkapan yang disandarkan kepada sahabat Ali bin Abi Thalib ra, meskipun ada juga yang mengatakan bahwa penisbatan itu keliru. Ungkapan tersebut adalah sebagai berikut:

$$
\text { الحق بلا نظام يغلبه الباطل بنظام }
$$

Kebenaran tanpa sistem (tak terorganisasi) akan dikalahkan oleh kebatilan bersistem.

\section{4. 'Imārah}

Kata al-imārah ( العمارة ) dapat diartikan mengurus atau memakmurkan. Dalam al-Qur'an kata ini digunakan untuk menyebut pengurusan terhadap masjidil haram, sebagaimana firman Allah Swt berikut:

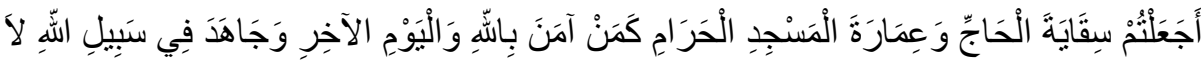

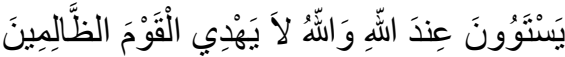

Apakah (orang-orang) yang memberi minuman orang-orang yang mengerjakan haji dan mengurus Masjidil Haram kamu samakan dengan orang-orang yang beriman kepada Allah dan hari kemudian serta bejihad di jalan Allah? Mereka tidak sama di sisi Allah; dan Allah tidak memberi petunjuk kepada kaum yang zalim (TQS. Al-Tawbah/9: 19).

Dari ayat yang memuat kata imārah inilah kemudian menjadi populer di Indonesia untuk menamakan pengurus masjid dengan sebutan ta'mir masjid, yang berarti panitia pembangunan atau pengurus yang bertugas memakmurkan masjid.

Dari empat kata yang digunakan untuk menyebut manajemen bisa dikatakan tidak satu pun yang persis sama secara keseluruhan untuk 
dipadankan dengan kata manajemen sebagaimana yang digunakan saat ini. Hal ini disebabkan karena kekayaan kata, variasi dan perubahan serta makna kata itu dalam bahasa Arab. Boleh jadi kata idārah cocok untuk makna manajemen dalam suatu konteks, tetapi pada konteks lainnya bisa jadi dia cocok dengan kata imārah atau nizāam, dan seterusnya. Karena itu, istilah-istilah tersebut dapat saling bergantian penggunaannya untuk menyebut kata manajemen dalam konteknya. Misalnya, ketika manajemen dimaksud terkait dengan aktivitas pengelolaan kerja sama yang bersifat adminsitratif, maka dapat menggunakan isilah al-idārah. Jika terkait dengan kegiatan manajemen yang erat kaitannya dengan kepemimpinan dan pengambilan keputusan manajemen, dapat menggunakan istilah tadbirr. Atau jika terkait dengan aspek keorganisasian, sistemasi dan standar prosedur, dapat menggunakan istilah nizạm atau al-tanzīmm.

\section{B.1 Manajemen dalam Sejarah Islam}

Sebagai sebuah praktik kerja sama antara dua atau beberapa orang, maka manajemen telah lama dikenal manusia. Bahkan dapat dikatakan, bahwa manajemen ada sejak adanya dua manusia di bumi ini. Karena itu, manajemen tertua yang dipraktikkan oleh manusia adalah sebagaimana yang dilakukan oleh Nabi Adam as. ketika mengatur dan membagikan pekerjaan di antara anak-anaknya sesuai dengan watak dan tabiatnya masing-masing. Habil yang berperasaan halus dan penyayang diberi tugas beternak sementaranya Qabil yang berperawakan kasar dan keras diberi tugas bertani atau berkebun bercocok tanam dan merambah hutan. Sedangkan anak perempuannya diberi tugas-tugas memasak, merawat dan membersihkan rumah serta tugas-tugas domestik lainnya (Bey Arifin, 1996: 25).

Begitu juga manajemen yang dilakukan oleh Nabi-Nabi yang datang sesudah Nabi Adam as., seperti Nabi Nuh as, Nabi Ibrahim as, Nabi Musa as, Nabi Isa as, sampai ke Nabi terakhir Muhammad Saw. Salah satu, karya Nabi-Nabi tersebut yang bersifat pisik dan paling monumental adalah 
Ka'bah yang dibangun kembali oleh Nabi Ibrahim bersama Nabi Ismail as.

Setelah berlalu masa yang begitu panjang, maka dicoba menyusun manajemen sebagai suatu ilmu pengetahuan yang dilakukan pada pertengahan abad ke-19 M. Para ahli menganggap bahwa manajemen ilmiah ini lahir dari peradaban Barat. Kelahirannya dilatarbelakangi oleh adanya kebutuhan untuk mengatur hubungan kerja sama antara individu dengan individu lainnya dalam masyarakat secara umum khususnya dalam lapangan bisnis.

Boleh jadi anggapan ini ada benarnya dari sisi menyusunnya sebagai sebuah disiplin ilmu. Akan tetapi, manajemen sebenarnya telah lama diterapkan dalam dunia Islam, bahkan ketinggian manajemen telah mengantarkan umat Islam menduduki tempat tinggi dalam hal peradaban di dunia ini selama belasan abad. Hanya saja, sebagai sebuah pengelolaan atau pengaturan kerja sama, maka sepanjang sejarah Islam tidak dianggap sebagai sesuatu yang penting untuk dijadikan disiplin ilmu yang dikaji secara terpisah. Manajemen pada waktu itu menyatu dalam pelaksanaan syariat dalam kehidupan Islam.

Beberapa jejak sejarah yang penting diungkap untuk menunjukkan kehadiran manajemen dalam peradaban Islam dapat dikemukakan sebagai berikut:

\section{Zaman Nabi Saw.}

Praktek manajemen yang paling menonjol di zaman Rasulullah Saw. terlihat ketika setelah hijrah dari Mekah ke Madinah. Adapun selama di Mekkah, manajemen Rasulullah Saw. lebih banyak terarah pada pelaksanaan dakwah. Secara umum, dakwah di Mekah meliputi dua tahap, yakni: pertama, dakwah sirriyah (sembunyi) yang dilakukan sejak masa $b i$ 'sah (pengangkatan sebagai Rasul) sampai hijrah ke Madinah. Dengan penuh kecermatan, Nabi Saw melakukan dakwah secara individu dan tersembunyi. Hal ini menjadi kemestian mengingat gagasan yang dibawa oleh Nabi Saw adalah sesuatu yang baru bagi masyarakat Quraisy. Seandainya Islam yang dibawa oleh Nabi langsung disampaikan secara 
terbuka dan terang-terangan bisa jadi ia akan mati sebelum tersebar karena pasti mendapat perlawanan sengit sementara belum ada orang-orang yang siap menjadi pengembannya.

Kedua, dakwah i'lan (terang-terangan) dengan menyeru orangorang Quraisy kepada Islam secara terbuka, bahkan menantang. Nabi Saw dengan tuntunan wahyu mulai menunjukkan kerusakan aqidah dan keburukan peradaban jahiliyah lalu menunjukkan aqidah Islam yang lurus dan kebaikannya. Dengan dakwah ini, Nabi Saw tentu mendapati orang yang mau mengikutinya dan juga mendapatkan penolakan dan perlawanan, terutama dari kalangan pemuka Quraisy. Dakwah secara terang-terangan ini berlangsung bersamaan dengan dakwah secara tersembunyi dengan agenda utama pembinaan.

Setelah terjadinya pristiwa Isra' dan Mi'raj, Nabi Saw mulai menempuh tahapan baru dalam dakwahnya yang lebih bersifat politis, yakni mencari himayah (perlindungan dan dukungan) dari para tokoh terkemuka baik di Mekah maupun di luar Mekah. Di Mekah, aktivitas ini dilakukannya sendiri, sementara di luar Mekah, terutama di Madinah ditugaskan kepada Mushab bin Umair untuk melakukannya sampai ia berhasil mendapatkan dukungan politik bahkan militer dari Madinah. Dengan dukungan penuh itulah, maka Nabi Saw melakukan persiapan hijrah.

Dari pristiwa hijrah, terlihat betapa manajemen yang dilakukan oleh Rasulullah sangat matang. Karena di malam terjadinya hijrah, orang Quraisy merencanakan pembunuhan terhadap Nabi agar jangan sampai hijrah, maka perencanaannya dipersiapkan antara Nabi Saw dengan Abu Bakar ra. Pembagian tugas pun dilakukan dengan beberapa petugas yan terdiri dari anak-anak Abu Bakar dan beberapa orang yang terlibat. Mulai dari penunjuk jalan, yang menangani logistik untuk perjalanan dan selama persembunyian di Gua Hira, pemonitor berita dan pergerakan Quraisy sampai penunjuk jalan yang disewa dari orang yang berpengalaman.

Periode setelah hijrah dimana umat Islam telah memiliki kekuatan dengan berdirinya Daulah Islam dengan Nabi Saw sebagai kepala 
negaranya. Dalam aspek ketatanegaraan, Nabi Saw. mengorganisasi kepemimpinannya menjadi beberapa jawatan dan wilayah (kewalian) yang dipimpin oleh seorang wali dan keamilan yang dipimpin oleh seorang amil. Untuk keperluan musyawarah, Nabi Saw menempatkan posisi sahabatsahabat senior sebagai anggota Majlis Syūrāa, di antaranya: Abu Bakar, Umar, Ali, Hamzah, Ja'far Raḍiya Allāhu 'anhum.

Dalam negeri, Nabi Saw menerapkan Islam secara menyeluruh dalam semua lapangan kehidupan. Terhadap nonmuslim, dilakukan pengaturan bahwa semua nonmuslim yang bersedia tinggal dalam naungan Islam diperlakukan sebagai ahl zimmi dengan hak dan kewajiban sama dengan umat Islam, kecuali mereka bebas dari kewajiban membayar zakat dan jihad. Terkait urusan luar negeri, Nabi Saw. menetapkan politik dakwah dan jihad. Bentuk hubungan luar negeri adalah dalam rangka melakukan dakwah mengajak kepada Islam. Jika mereka menolak, mereka dibiarkan dan ditawarkan untuk bergabung dengan wilayah Islam dengan tetap pada agama mereka masing-masing. Jika mereka juga menolak, maka mereka diperlakukan sebagai ahl al-harb dan boleh diperangi sampai mereka tunduk secara militer.

\section{Zaman Khulafaurrasyidin}

Era Khulafaurrasyidin diawali oleh Abu Bakr al-Shiddiq yang memerintah selama dua tahun (632-634 M), dilanjutkan oleh Umar bin aKhattab selama sepuluh tahun (634-644 M), Utsman bin Affan selama dua belas tahun (644-656 M) dan Ali bin Abi Thalib selama lebih empat tahun (656-661 M). Kondisi di zaman Khulafaurrasyidin tidak jauh berbeda dengan di zaman Nabi saw. Para khalifah pada umumnya hanya mengikut apa yang ditinggalkan oleh Nabi Saw, sehingga masa pemerintahan mereka juga dinamakan khiläfah 'alā minhaj al-Nubuwwah (pemerintahan yang tegak di atas manhaj kenabian).

Para masa Khulafaurrasyidin, wilayah Islam semakin luas. Meliputi seluruh jazirah Arab, wilayah Syam, sebagian Afrika dan Eropa. Wilayah yang luas itu diorganisasi menjadi beberapa wilayah dan dipimpin oleh 
seorang wali, baik wāli shalat (memimpin shalat dan sebagai simbol tugas mengurusi kepemimpinan/pemerintahan) maupun wāli māl (hanya mengurusi zakat dan urusan harta lainnya).

Dari segi manajemen pemerintahan, terlihat banyak hal menonjol di masa Umar bin Khattab. Di masa Umar, pertama kali Bayt al-Māl dipisahkan dari masjid, dilembagakan dan ditunjuk pengelola khusus agar dapat dikelola secara rapi. Selain itu, Umar juga menunjuk pelaksana pengadilan yang terpisah dari tangan khalifah (Ma'ruf Abdullah, 2012: 7). Khalifah membentuk lembaga peradilan dan menunjuk Qadhi untuk memutuskan perkara atau perselisihan di masyarakat. Selain itu, juga ditunjuk Qadhi Hisbah yang bertugas mengawasi dan memelihara ketertiban dan menjamin hak-hak masyarakat.

\section{Zaman Pasca Khulafaurrasyidin}

Pasca Khulafaurrasyidin terdapat tiga kepemimpinan dalam kurun waktu yang sangat lama, yakni diawali oleh kepemimpinan dari keluarga Bani Umayyah yang berpusat di Damaskus (661-750 M), Bani Abbasiyah yang berpusat di Bagdad (750-1258 M), dan Bani Utsmaniyah yang berpusat di Istambul Turki (1258-1924 M).

Pada masa kepemimpinan Bani Umayyah, manajemen belum banyak mengalami perubahan dari zaman Khulafaurrasyidin. Khalifah Muawiyah memindahkan ibukota negara dari Kufah ke Damaskus (Syria). Dalam aspek pemerintahan, Bani Umayyah melakukan pengembangan organisasi pemerintahan dengan membuat dīwān (lembaga, kantor atau jawatan) untuk mengurusi berbagai urusan, yakni: dīwān al-junūd (angkatan perang), dīwān al-kharaj (urusan kharaj dan keuangan), dīwān al-rasāil (surat menyurat dan kesekretariatan), dīwān al-khatam (pemegang stempel negara), dan dīwān al-barīd, semacam kantor pos (Ma'ruf Abdullah, 2012: 11).

Selain itu, perubahan mekanisme pemilihan calon khalifah dengan sistem pewarisan dari khalifah sebelumnya, mirip dengan sistem putra mahkota dalam pemerintahan kerajaan. Meskipun demikian, metode baku 
pengangkatan khalifah dengan bai'at tidak mengalami perubahan. Meskipun dari aspek pemerintahan banyak keburukannya terutama dari aspek nepotisme, tetapi juga terdapat banyak kemajuan yang dicapai. Sebagai contoh dalam penyelenggaraan pemerintahan di masa kepemimpinan Bani Umayyah bersifat Arabic centris, yakni mengutamakan para pejabat dari bangsa Arab sehingga simbol-simbol Islam yang memang tidak bisa dipisahkan dari Arab tetap terjaga. Di masa ini, banyak berkembang ilmu-ilmu syariat, terutama dan hadis dan fiqhi. Di masa inilah terjadi puncak kemajuan ilmu hadis ditandai lahirnya imam-imam hadis.

Dalam aspek pelayanan masyarakat (public servive) khalifah menerapkan manajemen berbasis pelayanan. Khalifah mengutamakan pelayanan dengan mengoptimalkan peranan komunikasi dan informasi atau hubungan masyarakat (Humas). Khalifah Abdul Malik bin Marwan senantiasa membuka pintu setiap saat siang dan malam untuk menerima informasi dan memberikan pelayanan kepada pegawai dan rakyat. Ia beranggapan bahwa keterlambatan pelayanan meskipun satu jam berarti kerugian satu tahun bagi pekerjaan negara (Fuad Mohd. Fachruddin, 1985: $51)$.

Masa yang paling terkenal di era pemerintahan Bani Umayyah adalah ketika Umar bin Abd Aziz menjadi khalifah. Selama dua tahun memimpin dengan manajemen pemerintahan yang berbasis pelayanan masyarakat berhasil membawa masyarakat mencapai kesejahteraan yang maksimal. Khalifah menerapkan perhitungan harta kekayaan bagi pejabat dan pegawai negara. Pegawai negara yang terindikasi mendapatkan kekayaan yang tidak wajar diwajibkan untuk mengembalikan ke kas negara. Hal itu dimulai dari diri khalifah dengan keluarganya dengan mengembalikan semua perhiasan yang diberikan oleh kahlifah sebelumnya.

Pada masa Abbasiyah, masalah pejabat pelaksana pemerintahan masih melanjutkan model pewarisan kekuasaan kepada keluarga-keluarga tertentu terutama keluarga khalifah. Jabatan-jabatan yang tidak terlalu strategis beberapa di antaranya diserahkan di tangan keluarga dari Persia 
sehingga pemerintahan banyak bercorak Persia.

Dalam menjalankan pemerintahan, Bani Abbasiyah mempunyai kebijakan memindahkan ibukota ke Iraq yang kemudian diberi nama Madīnat al-Salām atau Dār al-Salām (kota damai), tetapi kemudian diganti dengan nama Persia, yakni Baghdah yang berarti hadiah Allah. Untuk membangun ibukota ini, Khalifah al-Mansur mengundang seluruh insinyur terkenal untuk membuatkan gambar sebuah kota yang indah, aman dari banjir dan sebagai pelindung dari musuh. Para insinyur itu kemudian menggambar di atas tanah datar dengan menggunakan pasir, lalu diletakkan di atasnya bola-bola dari kapas yang kemudian disiram dengan minyak lalu dibakar sehingga terlihat jelas gambaran proyek yang akan dibangun (Fuad Mohd. Fachruddin, 1985: 75). Setelah perencanaan proyek selesai, pembangunan pun dimulai dengan mendatang ribuan pekerja ahli dari berbagai daerah. Bentuk kota yang dibangun membentuk setengah lingkaran yang saling berhadapan. Dalam setiap kelompok pemukiman masyarakat dibangun fasilitas sanitasi, pengolahan sampah, lembaga pendidikan, masjid, dan pasar, serta pusat layanan masyarakat yang semuanya relatif dekat dan dapat dijangkau dengan berjalan kaki.

Salah satu yang menonjol juga dalam aspek manajemen pemerintahan adalah dilembagakannya al-hisbah (pemeliharaan hak-hak umum masyarakat). Al-hisbah sebenarnya sudah ada sejak masa Khulafaurrasyidin, tetapi ditingkatkan lagi manajemennya pada masa ini. Al-hisbah merupakan lembaga kontrol yang bertugas menyelesaikan persoalan publik, menjaga ketertiban, menjaga adab dan tata krama, mengawasi pelaksanaan pasar agar sesuai prinsip-prinsip syariah dan melaksanakan amar ma'ruf nahi 'an al-mungkar secara umum (Ma'ruf Abdullah, 2012: 7).

Dalam masa pemerintahan Abbasiyah juga dikenal kemajuan di bidang manajemen pendidikan. Khalifah mendirikan lembaga pendidikan, lembaga riset dan penterjemahan yang dikenal dengan nama Bayt alHikmah. Selain lembaga resmi milik pemerintah itu, masyarakat juga 
dimotivasi untuk mendirikan lembaga serupa dan diberikan suntikan dana kepada pegiat ilmu pengetahuan. Maka berkembanglah lembaga pendidikan, ilmu dan sains sampai pada taraf yang tak tertandingi. Di semua kota dan daerah dibangun sekolah rendah sampai universitas dengan biaya penuh dari pemerintah. Semua warga negara, laki-laki dan perempuan, kaya dan miskin, muslim dan zimmy diwajibkan bersekolah secara gratis atau tanpa dipungut biaya (Fuad Mohd. Fachruddin, 1985: 85).

Dengan begitu menjelmalah pemerintahan Abbasiyah dan Daulah Islam menjadi negara adidaya, tempat tujuan semua orang untuk menuntut ilmu, teknologi dan belajar ketinggian peradaban. Tidak ketinggalan bangsa Barat Kristen waktu itu juga ikut menimba ilmu di negeri kaum muslimin lalu pulang ke kampungnya dan mengembangkan ilmu-ilmu itu sampai terjadinya kebangkitan mereka dalam bidang imu pengetahuan dan industri (renaisance).

Pada zaman Abbasiyah inilah yang dikenal dalam sejarah sebagai zaman emas kemajuan ilmu pengetahuan, sekaligus sebagai jembatan emas yang menghubungkan peradaban sebelum masehi dengan peradaban manusia modern. Namun, pemerintahan dengan segala kemajuannya mengalami stagnasi setelah pusat pemerintahan di Bagdad dilumpuh oleh pasukan Mongol pada tahun 1258 M. Setelah itu, pemerintahan Islam tidak lagi sehebat sebelumnya karena telah dilanda konflik kepentingan dan perebutan kekuasaan di kalangan elit sampai datangnya masa pemerintahan dari kalangan Bani Utsmaniyah di Turki.

Pemerintahan Utsmani bermula pada tahun 1300 M di Asia Kecil. Kekuasaannya meluas setelah berhasil menggabungkan hampir seluruh wilyah-wilayah Islam di bawah pemerintahannya. Utsmani terkenal kuat dalam bidang militer serta peralatan perangnya.

Dengan kekuatan itu, ia mampu memperluas pengaruhnya dan mengambilalih ibukota Romwi Timur, Istambul dan menjadikannya sebagai ibukota negara yang baru. Sampai abad 16 dan 17, Bani Utsmani di Turki merupakan adidaya dunia yang tak tertandingi kehebatannya. Pengaruh 
kekuasaannya itu meluas dari Barat sampai ke Timur. Dengan modal kekuatan militernya, tentara Utsmani sampai dapat memberikan bala bantuan untuk melawan penjajah Eropah atas nusantara terutama di Aceh (Fuad Mohd. Fachruddin, 1985: 157).

\section{Zaman Negara Bangsa}

Setelah berakhirnya pemerintahan Utsmaniyah yang berpusat di Turki pada tanggal 3 Maret 1924, maka negeri-negeri muslim terpecah menjadi banyak negara dan tidak lagi menginduk kepada satu kepemimpinan umum sebagaimana sebelumnya. Negeri-negeri muslim tersebut secara umum berada dalam jajahan negara-negara Barat dan Eropa selama bertahun-tahun. Dengan begitu, maka manajemen pemerintahan meskipun secara de facto ada yang di dipegang oleh kaum muslimin sendiri, tetapi sebenarnya berada di bawah kendali penjajah, terutama Inggris, Francis dan Rusia. Di Timur Tengah, negeri-negeri muslim umumnya di bawah kendali Inggris dan sebagiannya lagi oleh Francis.

Negeri-negeri muslim yang terjajah tersebut pada abad ke-20an sebagian besar berhasil memperoleh kemerdekaannya. Setelah merdeka, negeri-negeri muslim tersebut tidak serta merta bebas mengendalikan dan mengatur dirinya sendiri. Secara umum, manajemen pemerintahan menganut dan mengikuti sistem pemerintahan warisan penjajahnya, seperti demokrasi dan otokrasi atau kerajaan. Negeri-negeri yang berada di bawah bekas jajahan Inggris dan Francis di Timur Tengah pada umumnya berbentuk kerajaan. Adapun negeri-negeri muslim yang merdeka setelah perang duan kedua, yakni setelah pengaruh Amerika menggantikan Inggris, secara umum pemerintannya berbentuk demokrasi.

Dengan terpecahnya negeri kaum muslimin menjadi puluhan negara kecil, maka corak manajemennya pun mengalami perubahan. Perkembangan manajemen di negeri-negeri muslim tidak lagi merujuk pada masa keemasan dengan berpedoman pada prinsip-prinsip Islam, tetapi banyak dipengaruhi oleh teori-teori manajemen dari Barat.

Praktek maupun ilmu manajemen berkembang dengan pola sekular, 
yakni berpijak pada paradigma pemisahan nilai-nilai agama dari ilmu pengetahuan. Ilmuan Barat yang banyak mengkaji dan mengembangkan manajemen secara ilmiah seperti Taylor, Hendary Fayol, Babage, dan lainlainnya. Bahkan Taylor (Amerika 1856-1915) dianggap sebagai Bapak Manajemen Ilmiah dan Fayol (Francis 1841-1925) sebagai Bapak Administrasi Modern.

Perkembangan selanjutnya sampai sekarang, manajemen dianggap merupakan produk Barat yang tidak ada kaitannya dengan Islam. Hal itu disebabkan karena kajian sejarah manajemen dari zaman pra sejarah, lalu zaman awal sejarah, kemudian langsung lompat ke ujung masa sejarah dan berakhir di zaman modern. Masa awal sejarah diambi fakta dengan Pesatnya perkembangan agama Kristen Katolik disebabkan bukan hanya karena ajarannya yang menyuruh umatnya untuk mendakwahkannya, tetapi juga karena pengelolaan institusi gerejanya yang telah terurus dengan rapi (Harol Koontz dan Cyril O'Donnel, dalam Sondang P. Siagian, h. 17). Sementara bagian setelahnya terlupakan atau sengaja dilupakan, yakni bagian sejarah panjang dimana masa-masa dunia dikendalikan oleh Islam selama belasan abad, yakni dari zaman Nabi Saw. sampai runtuhnya pemerintahan Utsmani di Turki.

\section{B.2 Isyarat Manajemen dalam al-Qur'an}

Kristalisasi pemikiran manajemen muncul setelah Allah Swt menurunkan risalah-Nya kepada Nabi Muhammad Saw. Pemikiran manajemen dalam Islam bersumber dari al-Qur'an dan petunjuk-petunjuk Sunnah. Selain itu, ia juga berasakan pada nilai-nilai kemanusiaan yang berkembang dalam masyarakat pada waktu tersebut (Ahmad Ibrahim Abu Sinn, 2006: 28).

Pemikiran tentang manajemen sesungguhnya merupakan bagian dari pemikiran ilahi. Hasil pemikiran itu merupakan bagian dari syariah yang diturunkan kepada manusia. Hal pokok yang penting dan membedakan antara manajemen pada umumnya dengan manajemen dalam perspektif 
Islam adalah aspek keyakinan (teologis), aspek implementasi (budaya), dan aspek akhlak atau moral (Ma'ruf Abdullah, 2012: 63-73).

1. Aspek Keyakinan (teologis)

Dalam perspektif Islam, tidak ada ruang aktivitas yang kosong atau bebas dari nilai. Semua aktivitas manusia disandarkan pada nilai-nilai yang ditetapkan oleh Allah sebagai acuan penilaian dan pertanggungjawaban. Inilah yang dimaksud firman Allah berikut:

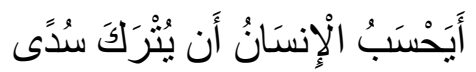

Apakah manusia mengira, bahwa ia akan dibiarkan begitu saja (tanpa pertanggung jawaban)? (TQS. al-Qiyamah/75: 36).

Berdasarkan ayat ini, maka manajemen sebagai bentuk aktivitas pengelolaan suatu kegiatan terkait dengan aspek keimanan. Bentuk nyata aspek keimanan itu adalah menyandarkan aktivitas manajemen pada apa yang diridhai oleh Allah Swt. Dengan demikian, subjek manajemen dalam Islam mesti menjadikan keyakinan adanya Allah sebagai pijakannya. Dengan meyakini adanya Allah Yang Maha Melihat, manusia akan selalu merasa diawasi dalam seluruh aktivitasnya. Dengan meyakini Allah Yang Maha Medengar, seseorang akan merasa selalu didampingi oleh Allah dalam berbuat sehingga tidak akan melakukan sesuatu yang dilarang-Nya. Dengan meyakini Allah Yang Maha Menghisab, maka seseorang akan menyadari betul adanya hari pembangkitan dan pertanggungjawaban.

2. Aspek Implementasi

Sebagai kelanjutan dari aspek teologi, dalam pelaksanaan manajemen mesti hadir sebuah kesadaran terikat dengan perintah-perintah dan larangan dari Allah Swt. Seorang manajer dalam menjalankan aktivitasnya menganggap hal itu sebagai bentuk ibadah yang akan mendapatkan ganjaran di akhirat.

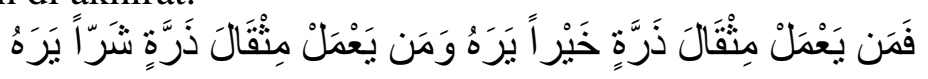

Barangsiapa yang mengerjakan kebaikan seberat dzarrahpun, niscaya dia akan melihat (balasan)nya. Dan barangsiapa yang mengerjakan 
kejahatan sebesar dzarrahpun, niscaya dia akan melihat (balasan)nya pula (TQS. al-Zalzalah/99: 7-8).

Dari sisi implementasi, manajemen tidak terpisahkan dari tuntunan Islam yang mengatur aspek tingkah laku yang mesti terikat dengan ajaranajaran Islam (terikat dengan hukum syara'), terutama aspek kerja sama dan interaksi sesama manusia. Pada aspek ini, Islam mengedepankan aspek tolong menolong dan keberkahan usaha. Dalam aspek syirkah misalnya, Islam melarang kerja sama bisnis yang hanya menguntungkan satu pihak dan mengabaikan hak-hak pihak lain. Karena itu, sebelum kerja sama itu dimulai, hal penting yang menjadi penentu adalah akad (komitmen awal) yang menandai dimulainya kerja sama itu. Dalam akad kerja sama tidak dibenarkan terjadi pelanggaran syariat yang berefek pada pelanggaran yang beruntun terjadi setelahnya. Misalnya, tidak boleh berakad dalam perkaran yang berbahaya dan diharamkan, tidak boleh berakad dalam masalah ekonomi yang terkait riba, judi dan manipulasi, serta eksploitasi tenaga dan sumber daya milik masyarakat. Begitu juga tidak boleh terjadi kerja sama yang dapat merendahkan martabat manusia dan kehormatan kaum wanita.

\section{Aspek Moral}

Aspek moral yang ada dalam manajemen perspektif Islam di antaranya adalah komitmen pada kejujuran, sikap amanah, dilakukan dengan ilmiah dan pendekatan komunikatif.

Kejujuran adalah satunya antara kata dan perbuatan. Dalam manajemen tidak dikenal istilah formalitas yang tidak sesuai dengan fakta. Dalam memberikan laporan misalnya baik lisan maupun tertulis tidak boleh berbeda dengan yang sesungguhnya hanya karena disesuaikan dengan format ajuan awal. Manajemen dalam Islam sangat menekankan kejujuran dan mencegah terjadi kezaliman. Dalam sebuah ayat, Allah Swt berfirman: 


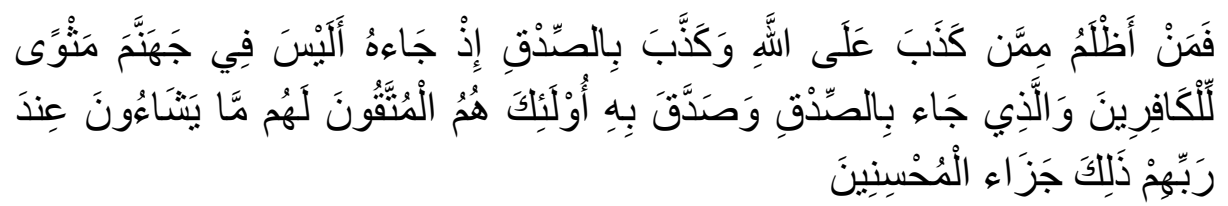

Maka siapakah yang lebih zalim daripada orang yang membuat-buat dusta terhadap Allah dan mendustakan kebenaran ketika datang kepadanya? Bukankah di neraka Jahannam tersedia tempat tinggal bagi orang-orang yang kafir? Dan orang yang membawa kebenaran (Muhammad) dan membenarkannya, mereka itulah orang-orang yang bertakwa. Mereka memperoleh apa yang mereka kehendaki pada sisi Tuhan mereka. Demikianlah balasan orang-orang yang berbuat baik (TQS. al-Zumar/39: 32-34)

Aspek moral yang lain adalah komitmen pada amanah. Amanah artinya kepercayaan sehingga orang yang amanah adalah orang yang dapat dipercaya. Kepercayaan orang lain atau pihak lain merupakan modal utama dalam menjalin kerja sama. Ketika kepercayaan ini hilang, maka kerja sama tidak dapat berjalan dengan baik. Kepercayaan itu akan muncul dengan sendirinya jika orang atau lembaga itu menepati dan menetapi aturan dan menuaikan amanah. Dalam al-Qur'an, Allah Swt berfimran:

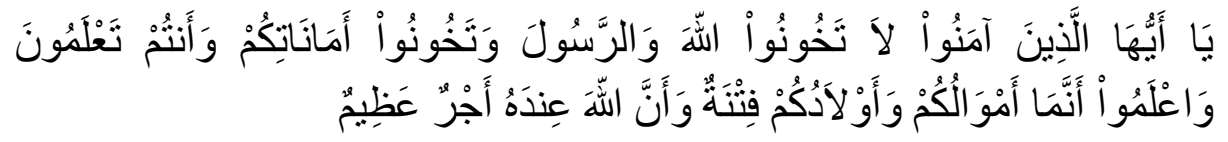

Hai orang-orang yang beriman, janganlah kamu mengkhianati Allah dan Rasul (Muhammad) dan (juga) janganlah kamu mengkhianati amanat-amanat yang dipercayakan kepadamu, sedang kamu mengetahui. Dan ketahuilah, bahwa hartamu dan anak-anakmu itu hanyalah sebagai cobaan dan sesungguhnya di sisi Allah-lah pahala yang besar (TQS. al-Anfāl/8: 27-28).

Jika dicermati perkembangan manajemen dewasa ini, tampak adanya perbedaan yang terdapat pada sisi aplikasi dan kajian pengembangannya. Manajemen modern menitikberatkan pada pencapaian hasil dan target-terget yang telah ditetapkan termasuk proses pelibatan 
manusia dalam kerja sama, tetapi mengabaikan sisi spiritual dan moral (akhlak) di dalamnya. Mengutamakan pemuasan stakeholder dengan mengabaikan sisi syariatnya. Bahkan cenderung fokus pada hasil dengan proses yang kurang mengindahkan aspek keimanan. Sebagai contoh, dalam manajemen pemasaran, dimana daya tarik dan pemuasan pelanggan lebih diutamakan sehingga berpeluang terjadinya eksploitasi aspek sensual ndan seksual perempuan, tanpa memperhatikan aspek akhlak dan ajaran Islam yang mengatur pola interaksi antara laki-laki dengan perempuan. Padahal dalam Islam tidak dibenarkan mempekerjakan kaum perempuan karena pisiknya, melainkan karena kemampuannya terhadap suatu bidang pekerjaan.

Dalam aspek pengawasan dan monitor, manajemen modern telah membenarkan memasuki wilayah yang seharusmya menjadi privasi orang lain, misalnya dengan melakukan monitor lewat alat visual seperti CCTV pada ruang kerja dengan mengabaikan aspek kepercayaan. Padahal dalam Islam, mestinya kerja sama dengan pihak lain mendahuluan aspek saling percaya dan bertanggung jawab.

\section{Penutup}

Kajian manajemen dewasa ini banyak dilakukan dan dikembangkan oleh Barat. Sementara kaum muslimin lebih banyak meniru dan memanfaatkannya saja. Kajian terhadap manajemen yang banyak dilakukan juga mensyarah apa yang dihasilkan oleh Barat. Padahal, manajemen sebenarnya lebih dahulu sudah dipraktekkan dan dikembangkan oleh umat Islam di masa kejayaannya dengan rentang waktu yang cukup panjang, mulai dari masa Rasulullah Saw., dilanjutkan oleh para Khulafaurrasyidin, kemudian masa pemerintahan Bani Umayyah, Bani Abbasiyah sampai masa akhir Bani Utsmaniyah di Turki. Ketinggian manajemen di masa ini terlihat dari warisan ilmu pengetahuan, sains dan peradaban umat manusia yang menjadi rujukan ilmuan sampai saat ini.

Kajian manajemen dalam Islam berbeda dengan manajemen pada 
umumnya. Perbedaannya terletak pada asas atau dasar praktek dan kajian manajemen yang dikembalikan pada akidah Islam yang bersumber dari alQur'an dan Sunnah. Dalam aspek implementasi, manajemen dalam Islam berpedoman pada ajaran-ajaran Islam secara umum yang mengatur interaksi manusia dengan berpola pada akhlak mulia, mengutamakan integritas, kompetensi dan ketulusan dan kecepatan dalam pelayanan. Ikatan dalam organisasi tidak semata disandarkan pada ikatan yang bersifat materi, seperti struktur organisasi dan tata laksana, tetapi lebih dari itu tercipta ikatan permanen baik berdasarkan aqidah maupun berdasarkan tanggung jawab secara transendental, karena merasa diawasi oleh Allah Swt. Faktorfaktor inilah yang membuat praktek dan kajian manajemen dalam Islam mnjadi unik. Nilai-nilai seperti ini tentu cenderung terabaikan dalam penerapan dan pengembangan manajemen paradigma sekuler saat ini. Namun dengan kebangkitan ilmuan muslim untuk mengisi kekurangan ini, maka ke depan kajian manajemen akan bersifat religius sehingga mengarah pada ketinggian peradaban.

\section{Daftar Pustaka}

Abdullah, Ma'ruf. 2012. Manajemen Berbasis Syariah. Yogyakarta: Aswaja Pressindo.

Arifin, Bey. 1996. Rangkaian Cerita dalam al-Qur'an. Cet. 15; Jakarta: alMaarif.

Benge, Eugene J. 1994. Elements of Modern Management. Diterjemahkan oleh Ny. Rochmulyati Hamzah dengan judul Pokok-pokok Manejemen Modern. Cet. 2; Jakarta: PT. Pustaka Binaman Pressindo.

Echols, John M. dan Hassan Shadily. 2007. Kamus Inggris-Indonesia. Cet. 29; Jakarta: PT. Gramedia.

Fachruddin, Fuad Mohd. 1985. Perkembangan Kebudayaan Islam. Cet. 1; Jakarta: Bulan Bintang. 
Goffar, Abdul. 2016. "Manajemen dalam Islam (Perspektif al-Qur'an dan Hadis)", ISLAMIK AKADEMIKA, Jurnal Pendidikan dan Keislaman. Vol. 8, No. 1, April.

Munawwar, Ahmad Warson. 1997. Al-Munawwir, Kamus Arab Indonesia. Cet. 14; Surabaya: Pustaka Progressif.

Al-Sa'diy, Abd al-Rahmān bin Nāṣir bin. 1420/2000. Taysīr al-Karīm alRahmān fì Tafsìr Kalām al-Manān. Juz 1. Cet. 1; Mu'assah alRisālah.

Sinn, Ahmad Ibrahim Abu. 2006. al-Idarah fi al-Islam, diterjemahkan oleh Dimyauddin Djuwaini dengan judul Manajemen Syariah, Sebuah Kajian Historis dan Kontemporer. Ed. 1, Cet. 1; Jakarta: PT. RajaGrafindo Persada.

Tim Penyusun Kamus Pusat Bahasa. 2002. Kamus Besar Bahasa Indonesia. Ed. 3, Cet. 2; Jakarta: Balai Pustaka.

Yacoeb, M. 2013. “Konsep Manajemen dalam Perspektifal-Qur'an: Suatu Analisis dalam bidang Administrasi Pendidikan". Jurnal Ilmiah DIDAKTIKA. Vol. XIV, No.1, Agustus. 